\title{
Bioetanol Sebagai Sumber Green Energy Alternatif yang Potensial Di Indonesia
}

\author{
A Review Article \\ Lily Arlianti \\ *Jurusan Teknik Kimia, Fakultas Teknik, Universitas Islam Syekh Yusuf, Jl. Mulana Yusuf No.10 Tangerang Banten \\ 15118 , Indonesia \\ larlianti@unis.ac.id
}

\begin{abstract}
Abstrak.
Ketersediaan bahan bakar fosil di dunia sudah semakin menipis, untuk itu bioetanol menjadi bahan bakar alternatif yang menjanjikan di masa depan. Indonesia sebagai negara yang memiliki sumber daya alam nabati yang kaya memiliki peluang besar menjadi negara produsen bioetanol. Bioetanol dapat dihasilkan dari tumbuhan yang mengandung pati dan lignoselulosa. Saat ini sudah banyak yang mengembangkan bioetanol dari limbah seperti limbah cucian beras, susu kadaluwarsa, limbah buah stroberi, limbah kulit nanas, limbah kulit dan bonggol pisang, limbah batang jagung dan sebagainya. Pada umumnya proses pembuatan bioetanol adalah dengan cara hidrolisis, fermentasi dan destilasi.Penelitian pembuatan bioetanol dari bahan-bahan yang lain ini akan sangat menarik untuk dikembangkan karena kebutuhan yang semakin meningkat dan sifatnya sebagai energi yang ramah lingkungan atau green energy.
\end{abstract}

Kata kunci: bioetanol, hidrolisis, fermentasi, destilasi

Abstract. Bioethanol As Potential Alternative Green Energy Source In Indonesia.

The availability of fossil fuels in the world is getting thinner, for that bioethanol becomes a promising alternative fuel in the future. Indonesia as a country with rich natural plant resources has a great opportunity to become a bioethanol producer country. Bioethanol can be produced from plants containing starch and lignocellulose. Currently there are many who develop bioethanol from waste such as rice wash waste, expired milk, strawberry fruit waste, pineapple skin waste, banana peels waste and banana stem, corn stalk waste and others. In general, the process of making bioethanol is by hydrolysis, fermentation and distillation. Research of making bioethanol from these other materials will be very interesting to be developed because of the increasing needs and the nature as environmentally friendly energy or green energy.

Keywords: bioethanol, hydrolysis, fermentation, distillation. 


\section{Jurnal Keilmuan dan Aplikasi Teknik \\ UNISTEK, 2018, Edisi 5, No.1}

\section{Pendahuluan}

Pertumbuhan penduduk dunia yang cukup tinggi dari tahun ke tahun dan diperkirakan saat ini sudah mencapai 7,6 miliar orang. Bertambahnya jumlah penduduk dunia ini berimbas dengan peningkatan kebutuhan sarana transportasi yang pada akhirnya mempengaruhi jumlah kebutuhan bahan bakar. Bahan bakar fosil merupakan bahan bakar terbanyak yang digunakan saat ini. Namun ketersediaan bahan bakar tidak terbarukan ini semakin menipis dan sudah tidak bisa diandalkan di masa yang akan datang. Untuk itu pencarian sumber energi alternatif untuk bahan bakar harus dikembangkan sehingga dapat diaplikasikan untuk penggunaan massal.

Saat ini sumber energi bahan bakar dari sumber alam sudah banyak dikembangkan. Salah satu sumber energi tersebut adalah bioetanol. Bioetanol sudah dikembangkan diberbagai belahan dunia dan saat ini Brazil dan Amerika Serikat merupakan negara produsen bioethanol terbesar didunia. Brazil memproduksi bioethanol dari tebu dengan jumlah produksi pada tahun 2004 sekitar 15 juta $\mathrm{m}^{3}$. Sedangkan Amerika Serikat memproduksi bioethanol dari jagung dengan produksi 14 juta $\mathrm{m}^{3}$ pada tahun yang sama. Sedangkan Spanyol menjadi negara terbesar di eropa yang memproduksi bioethanol.

Indonesia sebagai negara yang kaya dengan sumber daya alam memiliki kesempatan yang luas untuk pengembangan bioethanol ini untuk menggantikan sumber energi fosil yang semakin sedikit. Saat ini sudah mulai diproduksi bioethanol dari berbagai bahan baku seperti ampas tebu, singkong, kentang dan sebagainya. Pemerintah juga sudah memperkuat pengembangan bioethanol ini dengan Peraturan Presiden Republik Indonesia Nomor 5 Tahun 2006 tentang Kebijakan Energi Nasional untuk mengembangkan sumber energi alternatif sebagai pengganti BBM (Warsa, 2013).

\subsection{Bioetanol}

Bioetanol mempunyai rumus molekul $\mathrm{C}_{2} \mathrm{H}_{5} \mathrm{OH}$ dengan rumus bangunnya $\mathrm{CH}_{3}-\mathrm{CH}_{2}-\mathrm{OH}$ namun sering ditulis dengan EtOH. Bioetanol diproduksi dari biomassa yang mengandung gula, pati dan selulosa.

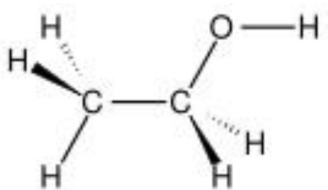

Gambar 1. Struktur molekul Bioetanol (Fessenden dan Fessenden, 1986)

Pemakaian bioethanol sebagai bahan bakar dapat dicampur dengan bensin dengan berbagai komposisi. Pemakaiannya memiliki kelebihan dan kekurangan.
Kelebihan pemakaian bioethanol adalah :

1) Bioetanol aman digunakan sebagai bahan bakar, titik nyala etanol tiga kali lebih tinggi dibandingkan bensin.

2) Emisi hidrokarbon lebih sedikit. Kekurangan-kekurangan bioetanol dibandingkan bensin:

3)Pada mesin dingin lebih sulit melakukan starter bila menggunakan bioetanol.

4) Bioetanol bereaksi dengan logam seperti magnesium dan aluminium (Setiawati, 2013).

Sebagai negara yang luas pertanian dan perkebunannya, Indonesia kaya dengan bahan baku untuk pembuatan bioethanol. Bahan baku bioetanol dapat diambil dari :

1) Bahan dengan kandungan glukosa tinggi

seperti tebu dan sisa produknya (molase, bagase), gula bit, tapioka, kentang manis, sorgum manis.

2) Bahan dengan kandungan pati tinggi (starchy materials) diantaranya ubi kayu, jagung, sorgum biji, sagu, tapioka, maizena, barley, gandum, padi, dan kentang.

3) Bahan lignoselulosa terdapat di berbagai sumber selulosa dan lignoselulosa yakni limbah seperti serat kayu, sekam padi, jerami, tongkol jagung serta limbah domestik berupa sampah organik.

\subsection{Hidrolisis}

Hidrolisa adalah suatu proses antara reaktan dengan air agar suatu senyawa pecah atau terurai. Reaksi ini merupakan reaksi orde satu, karena air yang digunakan berlebih, sehingga perubahan reaktan dapat diabaikan (Susanti, 2011).

Proses hidrolisis bisa dilakukan dengan 4 metoda yaitu :

1) Hidrolisis murni atau tanpa katalis, kekurangan proses ini berlangsung lambat karena hanya menggunakan air sebagai katalis.

2) Hidrolisis dengan asam, asam disini berfungsi sebagai katalisator untuk mengaktifkan air dari kadar asam yang encer. Biasanya asam yang digunakan adalah asam encer atau pekat.

3) Hidrolisis dengan basa, basa yang dipakai adalah basa encer, basa pekat dan basa padat. Reaksi bentuk padat sama dengan reaksi bentuk cair. Hanya reaksinya lebih sempurna atau lebih reaktif dan hanya digunakan untuk maksud tertentu, misalnya proses peleburan benzene menjadi phenol (Susanti, 2011).

4) Hidrolisis dengan enzim sebagai katalisator. Enzim adalah protein yang diproduksi dari sel hidup dan digunakan oleh sel-sel untuk mengkatalisis reaksi kimia yang spesifik. Hidrolisis enzimatis adalah proses pemecahan polimer menjadi monomer - monomer penyusunnya dengan bantuan enzim. Enzim amylase adalah enzim yang mampu menurunkan energi aktivasi sehingga dapat mempercepat pemecahan rantai polimer polisakarida 
menjadi monomer gula penyusunnya (Sari \& Moeksin, 2015).

\subsection{Fermentasi}

Fermentasi adalah proses perombakan senyawa organik dalam kondisi anaerob atau aerob yang menghasilkan produk berupa asam organik, alkohol dan gas.

Faktor-faktor yang mempengaruhi proses fermentasi adalah :

1) $\mathrm{pH}$ (derajat keasaman).

Untuk mencapai $\mathrm{pH}$ optimum dapat ditambahan asam seperti asam tartarat, malat atau sitrat. Biasanya selama fermentasi $\mathrm{pH}$ akan mengalami penurunan.

2) Suhu.

Temperatur optimal untuk Saccharomyces cerevisiae berkisar antara $25-30{ }^{\circ} \mathrm{C}$ dan temperatur maksimal antara $35-47^{\circ} \mathrm{C}$.

3) Jenis mikroba.

Pemilihan mikroba untuk fermentasi haruslah diperhatikan, mikroba yang baik adalah mikroba yang dapat tumbuh dengan cepat dan menghasilkan enzim-enzim essensial untuk proses fermentasi.

4) Oksigen.

Oksigen diperlukan untuk mikroorganisme yang bersifat aerob. Sehingga kecukupan okesigen akan mempengaruhi jumlah etanol yang terbentuk.

5) Nutrisi.

Mikroorganisme memerlukan nutrisi yang baik agar dapat memperoleh hasil fermentasi yang baik. Nutrisi utama adalah Nitrogen yang diperoleh dari penambahan $\mathrm{NH}_{3}$, garam ammonium, pepton, asam amino, urea. Nitrogen yang dibutuhkan sebesar 4001000 gr/1000 L cairan. Dan Phospat yang dibutuhkan sebesar $400 \mathrm{gr} / 1000 \mathrm{~L}$ cairan sedangkan ammonium sulfat sebesar 70-400 gr/1000 L cairan (Sari \& Santosa, 2013).

\subsection{Distilasi}

Distilasi atau penyulingan adalah suatu metode pemisahan larutan berdasarkan perbedaan titik

didih. Titik didih etanol murni adalah $78^{\circ} \mathrm{C}$. Proses distilasi akan meningkatkan kandungan etanol hingga $95 \%$. Sisa air yang masih ada dihilangkan dengan proses dehidrasi hingga kandungan etanol mencapai 99,5\% (Sari \& Moeksin, 2015).

\section{Metodologi}

\subsection{Bahan}

Bahan baku utama pembuatan bioetanol adalah bahan-bahan yang mengandung pati, gula atau lignosellulosa. Beberapa sumber yang penulis rangkum adalah dari molase, bonggol jagung, bonggol pohon pisang, kulit pisang, susu rusak, singkong, kulit nanas, batang jagung, nila kelapa, limbah cucian beras dan limbah stroberi. Untuk proses pembuatan digunakan ragi Saccharomyces cereviceae dan enzim amilase dan peralatan destilasi.

\subsection{Metode}

Pembuatan bioetanol melalui beberapa tahap yakni hidrolisis, fermentasi dan destilasi. Hasil destilasi inilah yang berupa bioetanol yang akan kita analisa dengan berbagai variabel seperti skema pada gambar 2.

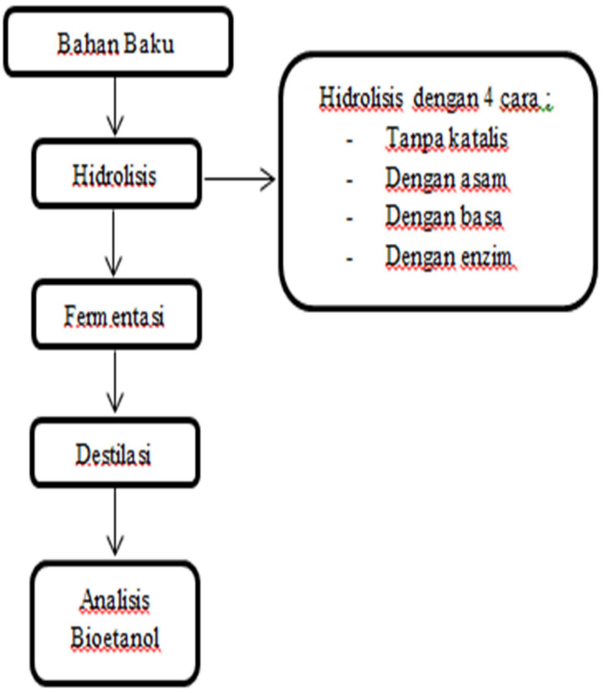

Gambar 2. Skema Pembuatan Etanol

Untuk bahan lignoselulosa pembuatan bioetanol melalui 4 proses utama yakni :

1) Pretreatment, untuk memecah ikatan lignoselulosa dan memisahkan lignin dari rantai polimer selulosa dan hemiselulosa.

2) Hidrolisis, untuk menghidrolisa polimer menjadi monomer.

3) Fermentasi, memfermentasi monomer menjadi etanol dengan menggunakan mikroorganisme.

4) Purifikasi, pemurnian etanol dengan melalui proses distilasi dan dehidrasi (Sari dan Moeksin, 2015).

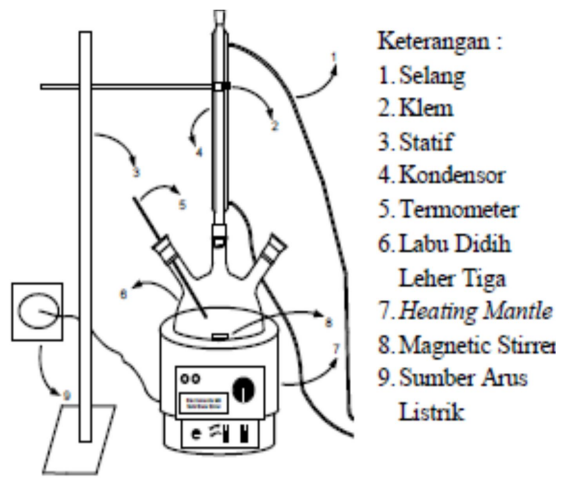

Gambar 3. Rangkaian alat Hidrolisis ( Miranda, 2014) 
Proses fermentasi terjadi didalam alat yang disebut dengan fermentor.

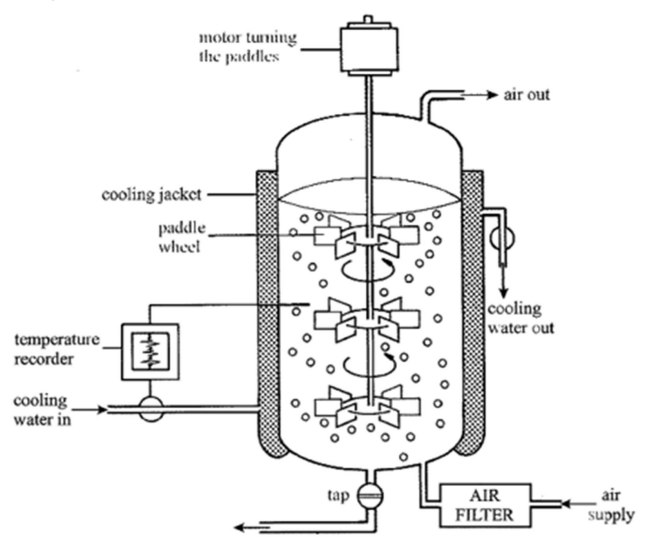

Gambar 4. Fermentor

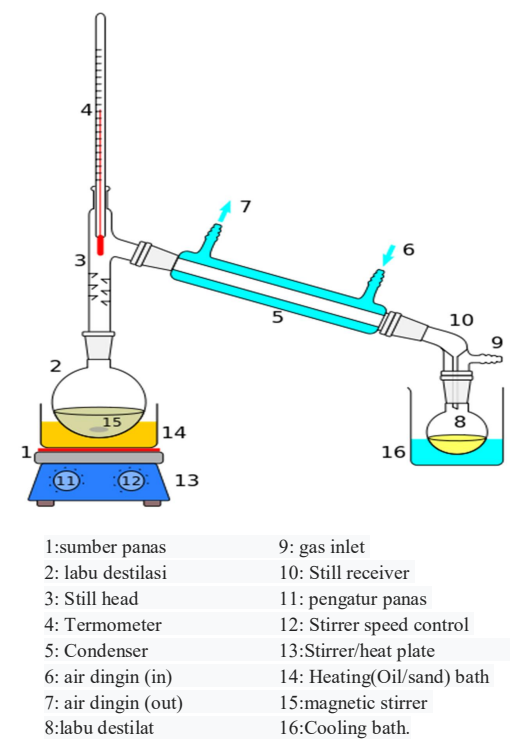

Gambar 5. Peralatan destilasi sederhana (sumber : Wikipedia)

\section{Hasil dan Pembahasan}

\subsection{Limbah Buah Pisang}

Pisang merupakan buah tropis yang banyak sekali dikembangbiakan di Indonesia. Pisang sudah menjadi buah yang paling digemari karena dapat dimakan langsung ataupun dibuat menjadi berbagai olahan seperti pisang goreng, pisang bakar, kue pisang, keripik pisang dan sebagainya. Pisang juga merupakan buah yang paling banyak diproduksi di Indonesia dimana menurut Badan Pusat Statistik pada tahun 2015 produksi buah pisang mencapai 7,29 juta ton kemudian diikuti oleh manga sebesar 2,2 juta ton. Dengan demikian pisang dapat menjadi bahan baku bioetanol yang menjanjikan di Indonesia.
Telah dilakukan penelitian bioetanol dari limbah bonggol pohon pisang dengan metode hisrolisis menggunakan enzim alfa-amilase dan gluko amylase kemudian dilanjutkan dengan fermentasi menggunakan saccharomyces cereviceae dengan kadar $8 \%, 9 \%$ dan $10 \%$ serta dengan variasi waktu ferementasi 2, 3, 5, 7 dan 8 hari. Dari penelitian ini didapatkan kadar saccharomyces cereviceae yang terbaik adalah $9 \%$ dengan waktu 7 hari yakni sebesar 30,59\% (I.W.Warsa dkk, 2013).

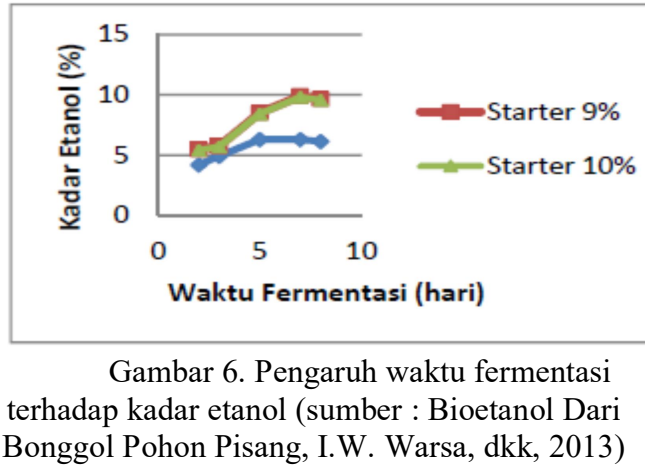

D.R.Setiawati dkk telah melakukan penelitian pembuatan bioetanol dari limbah kulit pisang kapok. limbah kulit pisang kepok mengandung monosakarida terutama glukosa sebesar $8,16 \%$ sehingga berpotensi sebagai bahan baku bioetanol. Peneliti melakukan percobaan dengan beberapa variabel yaitu $\mathrm{pH}$, jenis ragi dan konsentrasinya, waktu fermentasi dan perebusan sebelum fermentasi.

Jenis ragi yang dipakai adalah ragi roti dan ragi tape dengan variasi konsentrasi 1, 2, 3, 4 dan 5 $\%$ dari berat umpan, variasi $\mathrm{pH}$ mulai dari 2, 3, 4, 5 dan 6 serta waktu fermentasi 1, 2, 3, 4 dan 5 hari. Dari percobaan didapatkanhasil terbaik adalah fermentasi menggunakan ragi roti dengan konsentrasi $3 \%$ dari berat umpan, $\mathrm{pH} 4$ selama 2 hari dan dilakukan perebusan umpan terlebih dahulu yakni sebesar 9,7917\% bioetanol (D.R.Setiawati dkk, 2013).

\subsection{Limbah Kulit Nanas.}

Nanas merupakan buah yang sudah sangat dikenal dan digemari oleh penduduk Indonesia. Sentra produksi nanas meliputi Lampung, Jawa Barat, Sumatera Utara, Jawa Timur dan Jambi. Produksi nanas saat ini menurut sumber Kompas.com adalah 1,84 juta ton dan sudah mulai diekspor ke manca negara seperti ke Italia (Kompas.com, 11/06/2017).

Selama ini buah nanas selain dimakan langsung namun banyak juga diolah menjadi berbagai bahan makanan dan minuman. Konsumsi buah nanas inilah yang akan menghasilkan limbah kulit nanas yang dapat menjadi alternative bahan baku bioetanol. Sampah kulit nanas ini sekitar 34,61\% berat dengan kadar glukosa sekitar 17 \% (A.D.Susanti dkk, 2011) 


\section{Jurnal Keilmuan dan Aplikasi Teknik \\ UNISTEK, 2018, Edisi 5, No.1}

Limbah kulit buah nanas telah digunakan sebagai bahan umpan pembuatan bioetanol dengan metode hidrolisis menggunakan katalis asam $\mathrm{HCl}$. Variabel yang diamati adalah konsentrasi $\mathrm{HCl}$, waktu hidrolisis dan waktu fermentasi. Proses hidrolisa dengan konsentrasi $\mathrm{HCl} 0,3 \mathrm{~N}$ waktu reaksi 270 sampai 315 menit menghasilkan kadar glukosa terbesar yaitu 8,958 - 9,594\%. Proses fermentasi pada waktu 4 hari dan berat yeast 6 gram paling optimum karena menghasilkan kadar etanol 31,399\% dan konversi glukosa 58,62 \%. Kadar etanol total yang diprediksi diperoleh sebesar 31,399 \% (A.D.susanti dkk, 2011).

\subsection{Limbah Cucian Beras.}

Beras merupakan makanan pokok sebagian besar penduduk negara kita. Proses pemasakan beras untuk menjadi nasi sebelum dikonsumsi adalah melalui pencucian. Pencucian ini menghasilkan limbah yang saying untuk dibuang tanpa pemanfaatan. Limbah cucian beras ini mengandung karbohidrat yang dapat dimanfaatkan sebagai bahan pembuatan bioetanol.

Tabel 1. Komposisi kimia limbah cucian beras.

\begin{tabular}{lc}
\hline \multicolumn{1}{c}{ Unsur } & Kandungan $(\mathrm{g})$ \\
\hline Karbohidrat & 41,3 \\
\hline Protein & 26,6 \\
\hline Lemak & 18,3 \\
\hline Fosfor & 0,029 \\
\hline Kalsium & 0,019 \\
\hline Besi & 0,004 \\
\hline Vitamin B & 0,0002 \\
\hline \multicolumn{2}{c}{ (sumber : Erni.R dkk, 2015) }
\end{tabular}

Hasil penelitian pembuatan biopetanol dengan metode hidrolisis enzimatik dan fermentasi didapatkan hasil sebagai berikut .

1. Waktu hidrolisa yang lama dan penambahan enzim glukoamilase sebagai katalis dalam proses hidrolisa air cucian beras dapat meningkatkan kadar glukosa yaitu pada $3 \%(\mathrm{v} / \mathrm{v})$ penambahan enzim glukamilase dan 6 jam hidrolisa menghasilkan kadar glukosa 93,02 mg/L.

2. Waktu optimum fermentasi cucian air beras adalah 4 hari yang menghasilkan kadar etanol $11,177 \%$ (Erni. R dkk, 2015).

\subsection{Limbah Batang Jagung.}

Jagung merupakan salah satu makanan pokok penduduk Indonesia selain beras. Wilayah Indonesia yang menggunakan jagung sebagai makanan pokok adalah pulau Madura dan Sulawesi. Menurut Kementrian Pertanian produksi jagung pada tahun 2016 sebanyak 23,16 juta ton (Kompas.com 18/01/2017).

Batang jagung telah diuji coba sebagai bahan baku bioetanol dengan metode hidrolisis dan fermentasi menggunakan saccharomyces cereviceae. Penelitian ini bertujuan untuk mengetahui lama waktu fermentasi dan kadar etanol yang optimal yang dihasilkan dari proses fermentasi. Kegiatan penelitian diawali dengan penghalusan batang jagung, menjadi tepung dengan ukuran \pm 40 mesh. Kemudian dihidrolisis secara asam menggunakan $\mathrm{H}_{2} \mathrm{SO}_{4} 2 \%$, selanjutnya filtrat hasil hidrolisis di fermentasi menggunakan mikroba Saccharo-myches Cerevisiae, dengan variasi waktu fermentasi tiga, lima, dan tujuh hari. Hasil penelitian menunjukan bahwa waktu fermentasi optimal diperoleh pada variasi waktu fermentasi tiga hari dengan kadar etanol yang dihasilkan adalah 5,34\% (M.I. Yonas dkk).

\subsection{Limbah Susu Rusak.}

Susu merupakan bahan makanan yang melengkapi zat gizi yang dibutuhkan oleh tubuh manusia terutama usia bayi dan anak-anak. Susu rusak atau kadaluarsa dapat dimanfaatkan sebagai bahan baku bioetanol. Prametha \& Legowo sudah melakukan penelitian pembuatan bioetanol dari bahan baku susu rusak yang disubtitusi kulit nanas dengan metode fermentasi menggunakan saccharomyces cereviceae dari ragi merk "fermipan" sebanyak $1 / 10$ bagian volume substrat dengan variabel lama fermentasi 12(T1), 24 (T2), 36 (T3), 48(T4) dan 60 jam (T5).

Selanjutnya dilakukan proses destilasi untuk mendapatkan destilat yang berupa bioetanol. Destilat dimasukkan ke piknometer untuk mengetahui berat jenis dan kadar alkohol yang terbentuk. Selain itu dilakukan pengujian $\mathrm{pH}$ dan pengukuran produksi gas. Hasil percobaan dapat dilihat pada Tabel 3 dibawah ini.

\begin{tabular}{|c|c|c|c|}
\hline Perlakuan & $\begin{array}{l}\text { Kadar Alkohol } \\
(\%)\end{array}$ & ph & $\begin{array}{l}\text { Produks Gas } \\
\text { (L) }\end{array}$ \\
\hline$T 1$ & $2,09^{6}$ & $4,34^{9}$ & $1,31^{t}$ \\
\hline T2 & $2,75^{6}$ & $4,28^{\text {ib }}$ & $1,83^{\circ}$ \\
\hline T3 & $4,08^{\mathrm{ib}}$ & $4,09^{\mathrm{bex}}$ & $2,08^{6}$ \\
\hline T4 & $4,66^{\circ}$ & $3,92^{3 x}$ & $2,30^{\text {b }}$ \\
\hline TS & $4,25^{\circ}$ & $3,80^{\circ}$ & $2,45^{2}$ \\
\hline
\end{tabular}

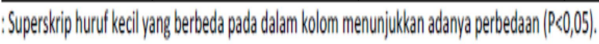

Tabel 2. Kadar alkohol, kondisi $\mathrm{pH} \&$ produksi gas (Prametha \& Legowo)

\subsection{Nira Kelapa}

Nira kelapa atau yang lebih dikenal dengan tuak telah dikembangkan sebagai bahan baku bioetanol oleh I.M.A Sutrisna Wijaya dkk dengan metode fermentasi, destilasi dan analisis kualitas bioetanol. Berikut bagan tahapan pembuatan bioetanol dari nira kelapa. 


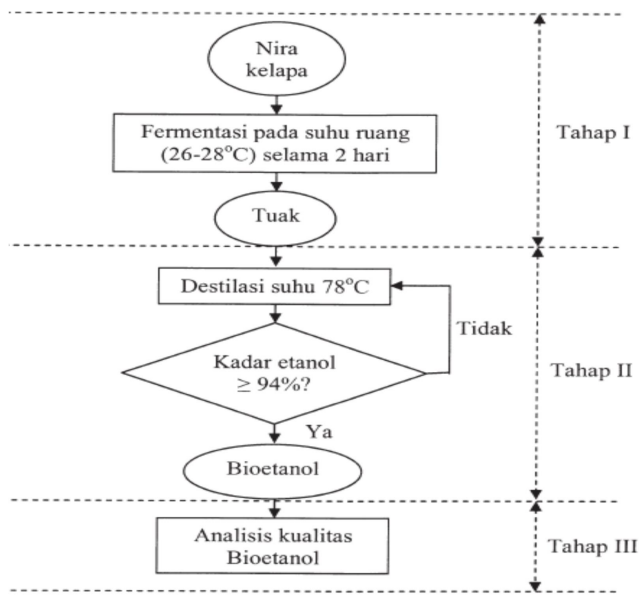

Gambar 7. Diagram alir penelitian (I.M.A.sutrisna Wijaya dkk, 2012).

Dari hasil penelitian didapatkan kadar etanol dari hasil destilasi menunjukkan destilasi ke 14 adalah kadar etanol optimum yang memenuhi standar SNI yakni $94 \%$.

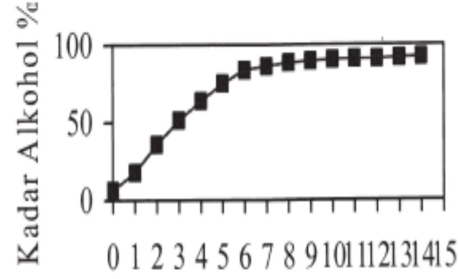

Destilasi ke

Gambar 8. Grafik Hubungan Kadar Alkohol dengan Frekuensi Destilasi

Peneliti juga menguji kualitas bioetanol yang dihasilkan dan hasilnya dapat dilihat pada Tabel 2.

\begin{tabular}{llrrrr}
\hline No. & Parameter kualitas & Ulangan I & Ulangan 2 & Ulangan 3 & Rata-rata \\
\hline 1 & Kadar Alkohol (\%) & 92,00 & 92,00 & 92,50 & 92,17 \\
2 & Kadar Ethanol (\%) & 95,00 & 94,30 & 96,10 & 95,13 \\
3 & Densitas (kgl) & 0,774 & 0,782 & 0,745 & 0,766 \\
4 & Specific Gravity & 0,793 & 0,801 & 0,764 & 0,780 \\
5 & API Gravity & 47,03 & 45,11 & 53,71 & 48,61 \\
6 & Nilai Kalor (kkal/kg) & $11.186,67$ & $11.143,99$ & $11.335,15$ & $11.221,94$ \\
\hline
\end{tabular}

Tabel 3. Kualitas alkohol yang dihasilkan dari nira kelapa (I.M.A.Sutrisna Wijaya dkk, 2012)

\subsection{Limbah Stroberi}

Buah stroberi dahulunya merupakan buah subtropik atau sering disebut buah impor dan termasuk buah yang mahal sehingga dikonsumsi terbatas oleh masyarakat kita. Namun dalam kurun waktu 1980-an stroberi mulai dikenalkan di Bali ditanam oleh masyarakat desa sekitar Candi Kuning. Sampai pada tahun 1991 mulai dikembangkan dan dikenal luas bersamaan dengan berdirinya PT Bali Berry Farms di desa Panca Sari, Bali.
Saat ini buah stroberi sudah ditanam diberbagai daerah dataran tinggi dan bersuhu sejuk dengan sebaran wilayah di pulau Jawa, Bali dan Sumatera. Stroberi selain dikonsumsi langsung juga sudah banyak diolah menjadi makanan dan minuman seperti selai, jus buah, sirup dan sebagainya. Kelemahan buah ini adalah teksturnya yang mudah rusak sehingga menghasilkan limbah.

A.M.Sari dan H.H. Santosa sudah melakukan penelitian bioetanol dari bahan baku limbah stroberi. Metode fermentasi menggunakan saccharomyces cereviceae dan penambahan urea dan NPK dengan variabel massa ragi adalah 0,$25 ; 0,5 ; 0,75 ; 1,0$ dan 1,25 waktu fermentasi $3,5,7$, 9, 11 dan 15 hari. Kemudian dilakukan destilasi untuk memperoleh etanol. Dari hasil destilasi didapatkan kemurnian etanol 3,04 dan rendemen $2,8 \%$ pada massa ragi optimum 0,75 dan waktu optimum fermentasi 11 hari. Hasil dapat dilihat pada Gambar 10.

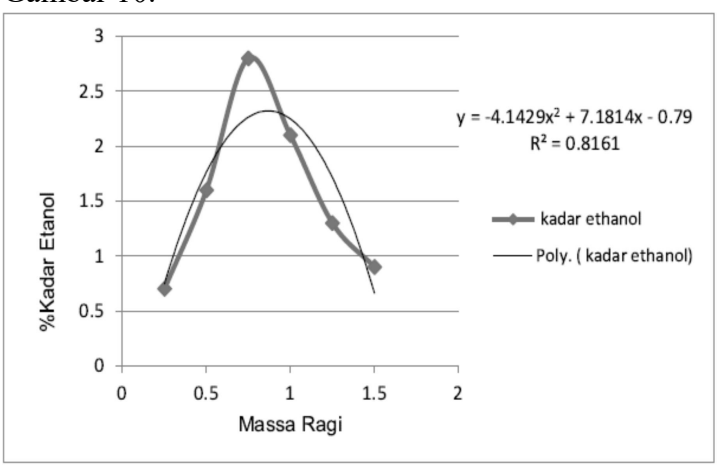

Gambar 9. Grafik Hubungan Massa Ragi Dengan \% Rendemen Bioetanol (Sari \& Santosa, 2013)

\section{Kesimpulan}

Indonesia sebagai negara tropis yang kaya akan keanekaragaman tanaman pertanian dan perkebunan membuka peluang besar untuk pengembangan bioetanol. Berbagai jenis umbiumbian, buah-buahan dan tanaman lignoselulosa lainnya menjadi sumber bahan baku bahkan limbahnya pun dapat kita manfaatkan untuk pengembangan bioetanol untuk menggantikan bahan bakar fosil.

Saat ini metode hidrolisis dan fermentasi masih menjadi pilihan untuk pengembangan karena murah dan mudah. Bioetanol akan menjadi primadona bahan bakar yang ramah lingkungan atau Green Energy dimasa yang akan datang dan Indonesia dapat menjadi salah satu produsen bioetanol terbesar di dunia karena luasnya ketersediaan bahan baku. Pemanfaatan limbah sayur, buah, makanan, minuman dan lainnya sebagai bahan baku bioetanol dapat juga menjadi solusi untuk penanggulangan limbah yang akan merusak lingkungan. Untuk itu perlu lebih banyak penelitian pengembangan untuk bioetanol ini. 


\section{Jurnal Keilmuan dan Aplikasi Teknik \\ UNISTEK, 2018, Edisi 5, No.1}

\section{Daftar Pustaka}

A.M.Sari \& H.H. Santosa,(2013), Pembuatan

Bioetanol dari Limbah Buah Stroberi (Buah Afkir), Konversi, Vol 2(2), 9-19.

B.Trisakti et.al., (2015), Pembuatan Bioetanol Dari Tepung Ampas Tebu Melalui Proses Hidrolisis Termal dan Fermentasi Serta Recycle Vinasse (Pengaruh Konsentrasi Tepung Ampas Tebu, Suhu dan Waktu Hidrolisis), Jurnal Teknik KimiaUSU, Vol.4 (3), 17-22.

I.W.Warsa, et.al., (2013), Bioetanol Dari Bonggol Pohon Pisang, Jurnal Teknik Kimia, Vol.8 (1), 37-40.

D.R.Setiawati, et.al., (2013), Proses Pembuatan Bioetanol Dari Kulit Pisang Kepok, Jurnal Teknik Kimia, Vol. 19 (1), 9-15.

Eni. R, et.al., (2015), Pembuatan Bioetanol dari Limbah Cucian Beras Menggunakan Metode Hidrolisis Enzimatik dan Fermentasi, Jurnal Teknik, Vol. 21(1), 1421.

Fessenden \& Fessenden, 1994, Kimia Organik, Jakarta: Erlangga.

I.M.A.S.Wijaya et.al., (2012), Potensi Nira Kelapa Sebagai Bahan Baku Bioetanol, Jurnal Bumi Lestari, Vol. 12(1), 85-92.

Miranda, et.al.,(2014), Hidrolisis Mikroalga Tetraselmis chuii Dengan Variasi Konsentrasi Asam Sulfat Dan Temperatur, Jom FTEKNIK, Vol.1(2), 1-5.

M.I.Yonas,et.al., Pembuatan Bioetanol Berbasis Sampah Organik Batang Jagung.

N.M.Prametha \& A.M.Legowo, (2013), Pemanfaatan Susu Kadaluwarsa dengan Fortikasi Kulit Nanas Untuk Produksi Bioetanol, Jurnal Aplikasi Teknologi Pangan, Vol. 2(1), 3035.

Susanti, et.al., (2011), Pembuatan bioetanol Dari Kulit Nanas Melalui hifrolisis Dengan asam, Ekuilibrium, Vol.10(2), 81-86. 